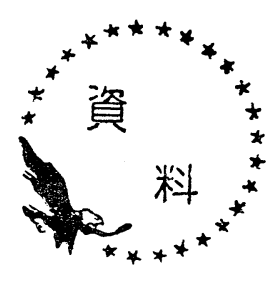

\section{石炭燃焼に上る貯湯式温水器}

一昭和 42 年 7 月 19 日 受理一

\section{I . 緒論——貯湯式温水器について}

燃料の燃焼または電熱によつて加熱した温水を, あ る程度の大きさの容器にためておき, 必要に応じてと り出して使用するものを貯湯式温水器という。40 $200 l$ 程度の貯湯容量を有するものが家庭用の温水器 として用いられる。用途としては, ち中ら房給湯用, 洗面用, シャワー用, 浴槽用, 浴場給湯用, などがあ る。わが国の国民生活の一般的な向上とともに家庭用 の給湯設備が次第に普及しつつあり, 貯湯式温水器の 需要も増加している。

貯湯式の温水器に対し, 貯湯容器を持たず, 供給さ れた水が加熱されてすぐ湯となつて出てくるものを瞬 間温水器 (湯わかし器) という。これには然料の点火 が容易で, その調節も簡単である所からもつぱらガス が然料として用いられている。普及といら点からは現 在最も多くの家庭で使われているものであろう。

瞬間式温水器は, 連続的に温度変化のない温水を供 給する場合（たとえばシャワー），一度に相当多量の 温水を必要とする場合（たとえば洋式の浴槽）には向 いていない。また貯湯式の温水器では比較的調節の困 難な燃料も使用することができ, 燃料費の低下を期待 できる利点もある。

家庭用の貯湯式温水器としては現在のところガスを 燃料とするものが多く, また電熱 (主として夜間の余 剩電力を利用するもの）もあるが，上記の燃料に関す る利点はあまり生かされていない。これは取扱いの便 利さがやはり重要な因子となつているからであろう。 しかし使用温水量が増加すると, もつと熱量単価の低 、燃料が要求されるようになるであろら。

以上のような理由で著者らは比較的多量の温水を利 用する貯湯式温水器とて, 新しい形式の石炭燃焼貯湯 式温水器を試作し, 研究を行なつた。以下にその構 造, 使用法, 実験の結果をのべる。

\section{II. 石炭燃焼貯湯式温水器の構造と使用法}

1. 構 造

この試作温水器は浴槽へ温水を供給することも考慮

\section{常磐炭礦株式会社 吉 田威 早稲田大学 小泉 睦 男}
1. 燃焼室
7. 煙 突
2. 燃焼室蓋
8. 断熱材 (斜線部)
3. 空気孔
9. 給水管
4. ポット
10. 温水出口管
5. 煙 管
11. 温水弁
6. ガス集合部
12. 冷水弁

\section{図 1 石炭燃焼貯湯式温水器の構造}

\section{表 1 石炭燃焼貯湯式温水器の主要諸元 (設計值)}

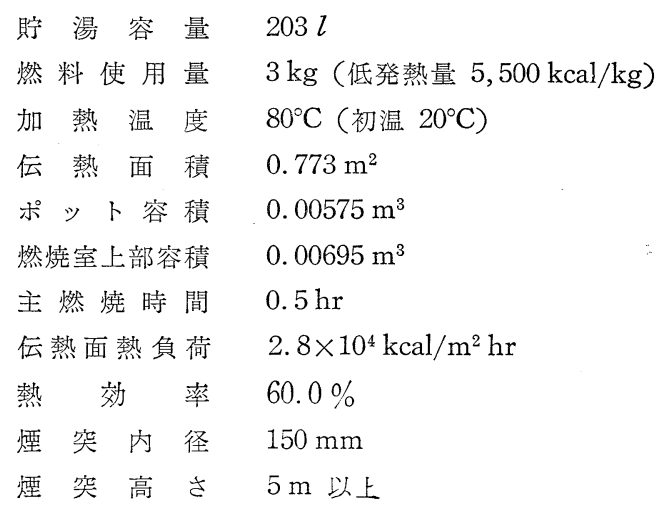


して貯湯容量を約 200 とした。その構造は図 1 に示 され，その主要諸元（設計值）が表 1 に示される。

2. 温水器の使用法

この温水器はポットにいれた一定量の石炭を全部燃 焼させ，それによつて慒内の水を一度に加熱し，その 後必要に応じて温水を使用する形式のものである。

温水器にはまず冷水を満しておく, その泠水温度, 必要とする温水温度, 外気温度などを考慮して石炭量 を定め，ポットにいれる。石炭量 $3 \sim 4 \mathrm{~kg}$ で $80^{\circ} \mathrm{C}$ の 温水が得られるように設計されている。

ポット内の石炭の層の上に着火郕をおき, 点火して 燃焼室内の所定の位置にポットを挿入し, 蓋をしめ空 気孔を適当にあけておく。そのままの状態で燃焼は自 動的に進行し，30min〜80 min で完全に燃えつきる。 空気孔からのぞいてポットの下に火の光が見えなくな つたら空気孔は閉めておく方がよい。石炭の灰は次回 の加熱の前にポットごと取り出す。

温水を使用するときは図 1 の温水弁をひらく。そう すると水道管からの水が温水器の下部に供給され, 内 部の温水をおし上げて, 温水出口から配管を通つて温 水が出てくる。温水の温度が高すぎる場合泠水弁を あけて適当に冷水を混合する。

温水器内の温水がほとんど完全に冷水に置換された 後,つぎの加熱を行なう。

3. この温水器の特徵

全体の構造としては比較的細長い形にしてある。こ のことにより据付面積を小さくし, 空間の利用率が高 くなる。また燃焼室から煙突まで然燒ガスが直上方に 向つて流れ，ガス流れの抵抗が少なく，空気の吸入が よいので着火が容易である。

伝熱面の主体は煙管であるが，ポット上方に十分な 燃燒室容積をとり,この部分で放射伝熱を活用してい る。

上面着火のポット燃焼 (下込燃焼過程)では上込燃 焼過程とくらべて不完全燃焼やすすの発生は少ない が，主燃焼期には不完全燃焼ガスを発生することがあ る。そこで使用石炭としては比較的火移り速度が遅 く, しかも然えきりのよい石炭(固有水分の多い石炭) を用いるのがよい。不完全燃焼ガスを出しやすい石炭 を用いる場合にはポットの高さを低くしてポットと上 部燃燒室の間のすきまから二次空気を適当に吸引する ようにするとよいであろら。

加熱に際しては温水器内の温水温度が最終的にはで きるだけ均一になるようにする必要がある。それには 温水器下部での加熱量を大きくするのがよい。その意
味で然焼室内の放射伝熱が有効に利用され, また煙管 もある程度の長さにとどめてある。特に燃燒ガスが温 水器の最上部をぬける所でもなお加熱が行なわれてい ると水温が上つた場合に上部で蒸気が発生したり伝熱 面に蒸気泡が停滞したりするおそれれがあ。そこで温 水器上部では煙突と温水槽の間に保温材をつめて伝熱 が行なわれないようにしてある。

温水をとり出すときには冷水を下部から送りこむの で, 温水器内で温水と冷水が混じて水温が低下寸るお それがある。これを防ぐのには給水管内を流れる水を 層流の状態にしておく必要がある。そうすれば温水と 冷水の比重差によつて温水は必らず冷水の上に乗り完 全に層状となつて分れる。したがつて温水はほとんど 温度低下寸ることなくその全部を利用することができ る。また温水弁, 冷水弁は一つの蛇口に二つの弁が組 合わせられたものを使用し，両手で同時に調節できる ようになっている。

この構造からわかるように温水器は温水出口管を通 じて大気に開放されているので圧力が上る心配は全く ない。

4. 実験によつて解明すい゙き点

上述のような構造の試作温水器について実験研究を 行なうに当たり,つぎのような点が特に検討の対象と なる。

a. 温水器内の温度分布 : 温水器内の温水の上下の 温度差はできるだけ小さいのが望ましい。その点を十 分顧慮して設計してあるがどの程度の温度分布となる かは実験で求めるほかない。

b. 温水を放置したときの温度降下 : 使用条件によ つては温水をつくつてからかなり長時間放置されるこ ともある。そのときの温度降下の程度を知る必要があ る。

c. 温水器の熱効率 : この温水器は燃料費が低いこ とが特徵であるから，その効果を発揮するために少な くとも設計の熱勃率は維持しなければならない。

d. 燃焼時間：燃焼している間は温水を使用しない のであるから，この時間はできるだけ短い方がよい。

\section{III. 実験結果とその検討}

\section{1. 実験結果}

長倉特号中塊および神の山小塊（表 2 参照）を用い て行なつた実験の結果を表 3 に示す。

加熱時における温水器内の温度変化の一例が図 2 亿 示される。温度測定の位置は図 3 に示されるとおりで ある。

燃焼排ガスの温度変化とガス組成の変化の一例が図 


\section{表 2 使用炭の組成と発熱量}

\begin{tabular}{|c|c|c|c|c|}
\hline \multirow{5}{*}{$\begin{array}{l}\text { 恙 } \\
\text { 盆 } \\
\text { 析 }\end{array}$} & & 柄 & 表倉特号中塊 & 神ノ山小塊 \\
\hline & 水 & 分 (\%) & 8.5 & 14.2 \\
\hline & & 分 $(\%)$ & 12.9 & 16.1 \\
\hline & 揮 発 & 分 (\%) & 44.7 & 32.8 \\
\hline & 固定䒚 & 纹素（\%） & 33.9 & 36.9 \\
\hline & 崖 & 素 (\%) & 65.3 & 64.0 \\
\hline 7 & & 素 (\%) & 5.4 & 4.9 \\
\hline 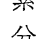 & & 素（\%) & 13.6 & 15.2 \\
\hline 朴 & & 素 (\%) & 0.8 & 0.8 \\
\hline & 燃焼性 & 主イオウ $(\%)$ & 0.5 & 0.3 \\
\hline & 量 $(\mathrm{k}$ & $\mathrm{cal} / \mathrm{kg}$ ) & 6,110 & 5,350 \\
\hline & 量 ( & $1 / \mathrm{kg}$ ) & 5,800 & 5,030 \\
\hline
\end{tabular}

4 と示される。

2. 燃焼時間と温水器効率

空気孔の開度を小さくすると空気流量が減じて，そ の結果燃狫時間が長くなる。ただし，空気流量は煙突 や煙管の閉塞の程度や, 風の状態などによつても影響 をうける。そこで空気流量はむしろ然燒時間から判定 される。その意味から燃焼時間に温水器効率との関係 をとると図 5 に示すようになり，かなり明瞭な相関が 市る。

設計值としては然焼時間を $30 \mathrm{~min}$ 程度としたが， これはポットの径の点からみて少し無理であつたよう である。実験值は $60 \mathrm{~min}$ 以上の值を示しているが， 燃燒時間が長いほど温水器效率法高くなる。温水器の

\section{表 3 実 験 結 果 (燃燒時間・熱効率)}

使用炭：長倉特号炭，燃料使用量 $3 \mathrm{~kg}$

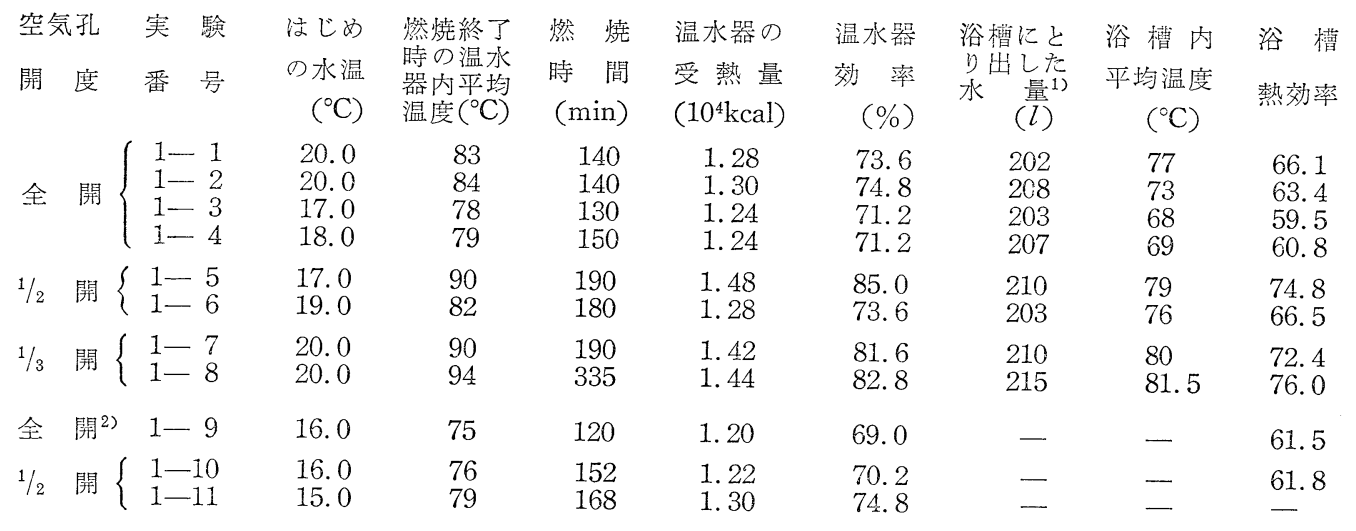

使用炭: 神, 山小塊, 燃料使用量 $3 \mathrm{~kg}$

\begin{tabular}{|c|c|c|c|c|c|c|c|c|}
\hline 全 開 & $\begin{array}{l}2-1 \\
2-2 \\
2-3\end{array}$ & $\begin{array}{l}20.0 \\
20.0 \\
19.0\end{array}$ & $\begin{array}{l}78 \\
75 \\
76\end{array}$ & $\begin{array}{l}163 \\
136 \\
146\end{array}$ & $\begin{array}{l}1.177 \\
1.115 \\
1.156\end{array}$ & $\begin{array}{l}78.0 \\
73.8 \\
76.6\end{array}$ & $\begin{array}{l}205 \\
205 \\
220\end{array}$ & $\begin{array}{l}69.0 \\
70.5 \\
83.0\end{array}$ \\
\hline $1 / 2$ 開 & $\begin{array}{l}2-4 \\
2-5\end{array}$ & $\begin{array}{l}16.0 \\
15.0\end{array}$ & $\begin{array}{l}75 \\
76\end{array}$ & $\begin{array}{l}172 \\
186\end{array}$ & $\begin{array}{l}1.198 \\
1.239\end{array}$ & $\begin{array}{l}79.3 \\
82.1\end{array}$ & $\begin{array}{l}205 \\
212\end{array}$ & $\begin{array}{l}70.5 \\
69.0\end{array}$ \\
\hline 開 & $\begin{array}{l}2-6 \\
2-7\end{array}$ & $\begin{array}{l}20.0 \\
21.5\end{array}$ & $\begin{array}{l}72 \\
82\end{array}$ & $\begin{array}{l}135 \\
170\end{array}$ & $\begin{array}{l}1.055 \\
1.229\end{array}$ & $\begin{array}{l}69.9 \\
81.4\end{array}$ & 203 & $\begin{array}{r}66.0 \\
-\end{array}$ \\
\hline $\begin{array}{l}\text { 2) } \\
\text { 開 }\end{array}$ & $\begin{array}{l}2-8 \\
2-9 \\
2-10\end{array}$ & $\begin{array}{l}16.0 \\
18.0 \\
17.0\end{array}$ & $\begin{array}{l}67 \\
68 \\
67\end{array}$ & $\begin{array}{r}105 \\
90 \\
120\end{array}$ & $\begin{array}{l}1.035 \\
1.015 \\
1.015\end{array}$ & $\begin{array}{l}68.6 \\
67.2 \\
67.2\end{array}$ & $\overline{\overline{1}}$ & $\overline{-}$ \\
\hline 開 & $\begin{array}{l}2-11 \\
2-12\end{array}$ & $\begin{array}{l}15.0 \\
19.0\end{array}$ & $\begin{array}{l}66 \\
70\end{array}$ & $\begin{array}{l}102 \\
126\end{array}$ & $\begin{array}{l}1.035 \\
1.035\end{array}$ & $\begin{array}{l}68.6 \\
68.6\end{array}$ & $\begin{array}{l}198 \\
199\end{array}$ & $\begin{array}{l}62.5 \\
65.0\end{array}$ \\
\hline 開 & $\begin{array}{l}2-13 \\
2-14\end{array}$ & $\begin{array}{l}18.0 \\
17.0\end{array}$ & $\begin{array}{l}70 \\
70\end{array}$ & $\begin{array}{l}122 \\
113\end{array}$ & $\begin{array}{l}1.055 \\
1.075\end{array}$ & $\begin{array}{l}69.9 \\
71.2\end{array}$ & 200 & 63.0 \\
\hline
\end{tabular}

1) 蛇口を出る水温が $45^{\circ} \mathrm{C}$ になるまでに浴槽にとり出された水量

2） 1-9 1-11，2-8 2-14 の実験は煙道内の掃除をした後の実験である。

保温がよいので，この結果は当然予想される所であ る。温水器効率が設計值より上回つているのはこのた めであつて，図における相関を延長すると然焼時間
$30 \mathrm{~min}$ の所で設計值に近い効率が得られることにな る。

燃焼時間を $30 \mathrm{~min}$ として火格子燃焼率を求めると 


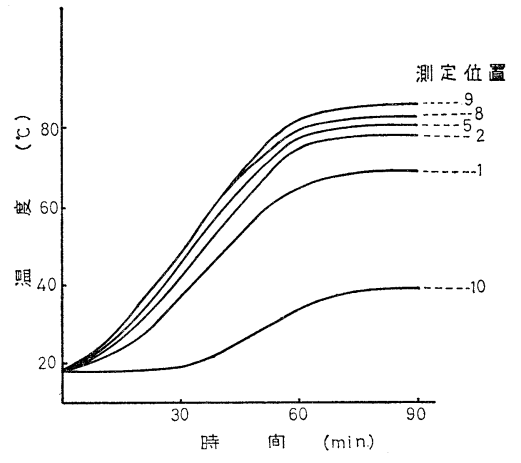

図 2 加熱時にbけ万温水器内温度分布

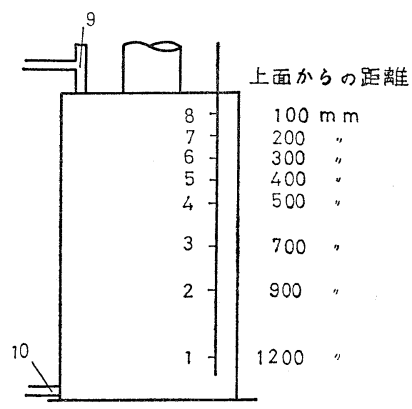

図 3 温水器内温度測定位置

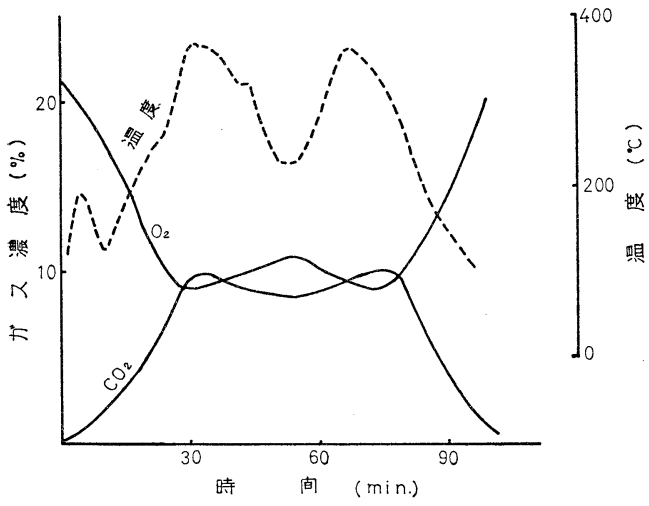

図 4 燃焼排ガスの温度とガス組成の変化

約 $188 \mathrm{~kg} / \mathrm{m}^{2} \mathrm{hr}$ となる。自然通風の場合の火格子然 燒率は $100 \mathrm{~kg} / \mathrm{m}^{2} \mathrm{hr}$ 程度とされているから，ポットの 径を $300 \mathrm{~mm}$ 程度とすれば所期の燃焼時間となるであ 5 。

3. 温水器内の温度分布

燃焼終了時の温水器内の温度分布は図 2 に示される ように予想以上に均一であつて,上下の温度差が $7 \mathrm{deg}$ を越えない。これは然焼・加熱中には内部の水の流動

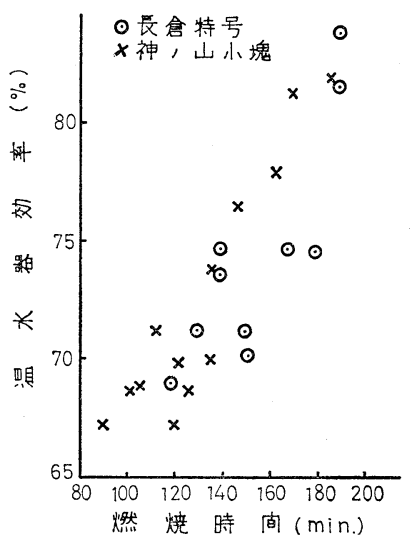

図 5 燃焼時間と温水器倅率

がきわめてよいことを示している。特にポットの位置 より上ではほとんど温度差がないといつてよい。

したがつて上部のみ過熱されるという心配は全くな い。また貯湯量 $203 l$ がほとんど完全に温水として利 用できることを示している。

4. 燃焼過程

図 4 に示されるように主然焼過程はポットの下込燃 焼に特有な二つの過程に分けられるよらである。すな わち燃焼帯が火格子面まで到達する火移り期と, 火格 子上に残された炭素が下から上へ然え上つていく燃 え上り期とである。

火移り期の前には着火期があつて燃焼ガス温度やガ ス中の $\mathrm{CO}_{2}$ は点火後はじめはゆっくりと，後に次第 に加速的に上昇する。これは自然通風なので然焼ガス の温度上昇と空気流量の増加が相互に影響しあらこと にもよるが，着火そのものに要する時間，炭層表面全 体に着火部がひろがる時間も関係している。炭層表面 全体が一度に着火するよらな点火方式を用いれば，も つとすみやかな燃焼ガス温度の上昇がみられるであろ 5。

燃え上り期のあとの後然え期は非常に短かく， $\mathrm{CO}_{2}$ 濃度はきわめてす夕やかに低下して0となる。これは 使用燃料が水分の多い非粘結炭であることによるもの で，この種の石炭が，この装置に適合していることが わかる。

5. 放熱による温度降下

温水をつくつてからしばらく放置する場合，保温材 を通しての放熱によつて温水の温度が徐々に降下す る。この温度降下の程度をしらべるために行なつた実 験の結果が図 6 に示される。冷却とともに温水器内上 下の温度差はややひらく傾向があるが, 平均温度につ 


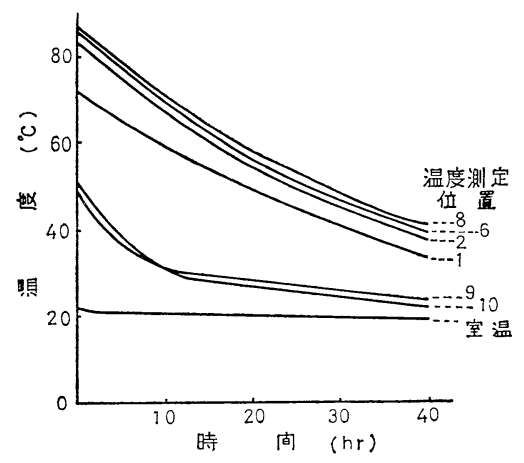

図 6 加熱した温水器を放置した場合の 温水温度の降下

いて冷却曲線の近似式を求的ると

$$
\theta-\theta_{0}=\left(\theta_{i}-\theta_{0}\right) e^{-\frac{t}{40}}
$$

となつた。ここで $\theta_{i}, \theta$ は温水器内の温水の初温およ びある時刻における平均温度 ${ }^{\circ} \mathrm{C}, \theta_{0}$ は外気温度 ${ }^{\circ} \mathrm{C}, t$ は実験開始からの時間 hr である。すなわち時定数 40 hr の一次泠却曲線で近似できる。これは外気温度と の差が $40 \mathrm{deg}$ のとき毎時 $1 \mathrm{deg}$ の温度降下があるこ とを示す。

したがつて就㷃時に加熱しておいて翌日早朝に温水 を利用するときの温度降下は $10 \mathrm{deg}$ 以内にとどまり， 早朝に十分高温の湯水を用いることができる。

6. 温水のとり出し速度

試作の装置は給水管として $3 / 8$ B ガス管 (内径 12.7 $\mathrm{mm}$ ）を用いたので層流という条件では温水のとり出 し速度は最高 $1.2 \mathrm{l} / \mathrm{min}$ となり，実用には少なすぎる ようであつた。事実 $200 l$ の浴槽に温水を満すのに $60 \mathrm{~min}$ 以上の時間をかけている。もつとも $45^{\circ} \mathrm{C}$ の水 200 をうるには $30 \mathrm{~min}$ でよかつた。
給水管として $1 \mathrm{~B}$ 方ス管 (内径 $27.6 \mathrm{~mm}$ ) 在用小れ ば温水を $2.5 \mathrm{l} / \mathrm{min} と り$ 出すことができる。

$$
\text { IV. ま と め }
$$

以上の実験結果から，試作温水器心給水管を $1 \mathrm{~B}$ ガ ス管とすれば十分実用に耐えるものだあることがわか つた。

もらろん商品化にあたつては底部の鹰食防止（䄚内 は常に満水しているので酸化は之机ほざはげしくな い，槽内の温水の置換程度の検出装置などき的の細 かい改良を必要とするが，いずれも技術的にそれほど 困難なものではない。

実用装置として本温水器の特色はつぎの点にある。

（i）有効熱量当たりの然料費が低いこと：実験に は中塊炭と小塊炭を用いたがその差䝂は少なく，粉炭 に近いものの使用も可能で，そうすればさらに燃料費 の低減ができる。ただし一回ごとに着火剤を用いるの で，安くて火つきのはやい着火成の開発が必要であ る。

(ii）石炭燃焼としては手間がかからないこと：石 炭燃燒の装置は一般に手間がかかると考えられている が，本装置ではポットにに石炭をいれて点火すること （煙突の構造が悪くなければ容易に着火する），ポット ごと灰をとり出して捨てること，の二つの作業で一日 分の温水が得られる。

そのほか貯湯式温水器としての特徵を持ち，また然 料が石炭であるから安全性が高い。

以上の点から本考案の貯湯式温水器は一日に 15,000 $\mathrm{kcal}$ 程度以上の温水熱量を要する場合に非常に有効な ものと思われる。

なお本実験の遂行には早稻田大学生 金谷善治君， 高見忠臣君の協力があつた。記して謝意を表する。

\title{
Coal Firing Hot Water Boiler for Domestic Use
}

\author{
by Takeshi Yoshida \& Mutsuo Koizumi \\ (Joban Coal Mining Co., Waseda University)
}

SYNOPSIS:-A new type of hot water boiler for domestic use is deviced. The boiler, a vertical cylinder $500 \mathrm{~mm}$ in diameter $1300 \mathrm{~mm}$ in hight $200 l$ in volume, is heated by coal which is fired in a cylindrical pot placed at the center of the bottom of the boilor. Combustion gas goes upwards through smoke tubes and is exchausted to a chimney. About $3 \mathrm{~kg}$ of coal is burned in one time and water is heated from about $20^{\circ} \mathrm{C}$ to $80^{\circ} \mathrm{C}$, then the hot water is used until it is almost replaced by the cold water. As the result of experments, it is shown that the thermal efficiency of the boiler is of $67 \sim 82 \%$ and heating time is about 1 hour. 